\title{
ADVANTAGES OF SUSTAINABLE TOURISM \\ IN THE FUNCTION OF DEVELOPMENT OF RURAL AREAS OF REPUBLIC SERBIA - EXAMPLE OF WINERIES
}

\author{
Tatjana Jovanović ${ }^{1}$ \\ Olga Gavrić ${ }^{2}$
}

DOI: https://doi.org/10.31410/tmt.2019.371

\begin{abstract}
Sustainable development is becoming a key factor in explaining the increasing socio-economic changes in our country and in the world. A common feature of sustainable and rural development is the insistence on the diversity of rural areas, which emphasizes their self-sustainability with adequate strategies and innovative solutions. The aim of the paper is to examine the potential of wine tourism in the context of adopting the principles and standards of sustainability in Serbia. In this connection, the subject of this paper is to point out the importance of the connection between sustainable and rural development, multifunctionality of agriculture and wine tourism in rural areas of the Republic of Serbia.
\end{abstract}

Keywords: Sustainable Development, Multifunctional Agriculture, Wine Tourism, Rural Development.

\section{INTRODUCTION}

$\mathrm{T}$ he increasingly visible and frequent presence of climate change, the scarcity of resources, have put the importance of using and applying the principles of sustainable development. The very notion of sustainable development indicates a process of qualitative growth that includes economic, cultural and social development in general. It is ,a development that meets current requirements without limiting the ability of future generations to meet their needs" (Bogdanov, 2015, p. 59).

An important step in the development of the Sustainable Development Strategy and Concept are also activities at the global, national and local levels in all areas where the environment is directly or indirectly affected.

In response to the increasing threat and degradation of living space, this paper aims to point out the importance of linking sustainable and rural development, multifunctionality of agriculture and rural tourism in rural areas of the Republic of Serbia. The multifunctionality of agriculture contributes to the strengthening of the concept of a healthy and preserved environment, the safety and quality of food, the conservation of air, water and biodiversity, with strict application of environmental standards and principles. The symbiosis of sustainable development and multifunctionality of agriculture is expressed most explicitly through the strengthening of links between agriculture and other branches of agriculture. In doing so, rural tourism embodied through its special segment such as wine tourism deepens and strengthens this connection. The expansion and development of wine tourism contributes to the adoption of specific sustainability principles. The vision of sustainable tourism, which is gaining in importance, enables the more efficient use of ecological resources, as well as highlighting the specificity and diversity of individual geographical regions and their inhabitants.

\footnotetext{
1 Agrifaculty, University of Belgrade, Nemanjina 6, Zemun, Serbia

2 Agrifaculty, University of Belgrade, Nemanjina 6, Zemun, Serbia
} 
The problems of rural areas of Serbia are very heterogeneous. The most significant ones are those related to depopulation, imbalances in rural development, high labor force involvement, uncompetitive agriculture, low level of integration of agriculture and food industry, etc. (Jelic, Jovanovic, 2018, p. 204).

Rural areas are increasingly geared towards the development of rural tourism, for which the Republic of Serbia has significant natural resources. The comparative advantages for the development of agriculture and tourism are based on numerous natural resources, rich flora and fauna, mineral resources, spring waters and unpolluted air, etc.

\section{SUSTAINABLE DEVELOPMENT}

Sustainability is one of the dominant development paradigms of the world economies. This multidimensional concept integrates the environmental, economic and social component, emphasizing the importance of sustainability in the long term.

There are several definitions of the concept in the literature, but the primacy has the 1987 Brundtland Commission definition, which claims that sustainable development is one that meets the needs of the present without compromising the ability of future generations to meet their own needs (Jovanović Gavrilović, 2008). Also, sustainable development is a prerequisite but also the ultimate goal of an efficient organization of human activities on Earth (Pešić, 2012).

The very concept of sustainable development is also viewed through the prism of 17 global goals that were defined and adopted in 2016 (UNDP, 2016). The goals are very complementary and interconnected, so the success of one goal depends on seeing the challenges that another goal brings with it. On the other hand, an integrative approach ensures the achievement of goals and the effective implementation of sustainability principles at the same time. Accordingly, the Sustainable Development Goals represent a kind of inclusive agenda, as set out in Table 1.

Table 1. Global goals of sustainable development

\begin{tabular}{|c|c|}
\hline $\begin{array}{ll}\text { 1. } & \text { No poverty } \\
\text { 2. } & \text { Zero hunger } \\
\text { 3. } & \text { Good health and well being } \\
\text { 4. } & \text { Quality education } \\
\text { 5. } & \text { Gender equality } \\
\text { 6. } & \text { Clean water and sanitation } \\
\text { 7. } & \text { Clean and affordable energy } \\
\text { 8. } & \text { Decent work and economic growth } \\
\text { 9. } & \text { Industry, innovation and infrastructure }\end{array}$ & $\begin{array}{l}\text { 10. Reduced inequalities } \\
\text { 11. Sustainable cities and communities } \\
\text { 12. Responsible consumption and production } \\
\text { 13. Climate action } \\
\text { 14. Life bellow water } \\
\text { 15. Life on land } \\
\text { 16. Peace, justice and strong institutions } \\
\text { 17. Partnership for the goals }\end{array}$ \\
\hline
\end{tabular}

Source: https://www.rs.undp.org/content/serbia/sr/home/sustainable-development-goals.html

The presence of climate change, resource scarcity and environmental devastation have further emphasized the importance of implementing sustainable development principles. The resource problem is best described through the Seneca effect that implies that economic growth based on resource exploitation is slow and achievable but generates pollution and waste which ultimately leads to decline and economic collapse (Bardi, 2017). On the other hand, the consequences of global warming represent one of the priority problems to be addressed in the coming period. Climate change is a direct consequence of GHG (Greenhouse gasses) over-emissions and the creation of a greenhouse effect on that basis. Specifically, according to the UNDP (United Nations Development Program), about \$ 100 billion is needed annually, to effectively manage 
climate change with a focus on mitigating the effects of natural disasters ${ }^{3}$ as other forms of adaptation to temperature change.

The implementation of the principles of sustainable development not only contributes to the achievement of the aforementioned global goals, but also represents a kind of challenge, i.e. a chance to develop and improve the competitiveness of the economy and industries. In this regard, the use of renewable energy sources in production processes is one of the main indicators in the context of monitoring the adoption and implementation of long-term sustainability goals. The concepts of circular economy, energy efficiency, and recycling represent a direct concretization of the idea of sustainable development. With all this in mind, one of the focuses of the work will be on looking at the potential of sustainable development as a driver of tourism development in rural areas of Serbia with an emphasis on wine tourism.

In addition to the benefits and overall potential of sustainable development as a driver of economic growth, there are certain disadvantages that we need to address in our work. Namely, the mentioned shortcomings represent an obstacle in the implementation of the concept and the achievement of the goals. In this regard, (1) the neglect of the time dimension, (2) the presence of false sustainability, (3) the lack of commitment and collaboration, and (4) the lack of understanding of the essence of sustainability, most often contribute to inadequate performance and results (Holmberg, 2009).

\subsection{Renewable sources of energy}

Alternative sources represent the personification of the circular economy as one form of implementation of the sustainability concept in practice. A common feature of all renewables is that their use reduces $\mathrm{CO}_{2}$ emissions as a major contributor to the greenhouse effect and global warming presence. Not only is cleaner, alternative energy more energy-efficient and productive from the perspective of the potential of green production in an economy. The use of alternative energy sources is in the function of achieving the global goals of sustainable development, since the form of renewability implies creating equal conditions for the life of future generations (Stojadinović, 2011). Generally, there are several forms of renewable energy sources: biomass, water, wind, sun, geothermal and high/low tide.

Bearing in mind, the above specifics, in practice, however, fossil fuels have primacy. There are several reasons for this. First, the cost of energy generated from the use of renewable energy sources is incomparably higher than that obtained using fossil fuels. Second, the total cumulative energy resulting from the use of water, sun and wind is insufficient to meet the demand for energy. Accordingly, the best balance is the use of renewable and non-renewable resources, with an emphasis on effective management of pollution and climate change. Finally, the use of alternative forms of energy involves the presence of high cost infrastructure (solar panels, wind turbines).

At EU level, the 2020 Strategy was defined, as well as the 7EAP (7th Environmental Action Plan), which foresees a greater use of renewable energy sources by $20 \%$, an increase in energy efficiency by $20 \%$, and a reduction in GHG emissions by $30 \%$ compared to 1990 . (SOER, 2015). Based on the strategy as a broader framework, policies and other measures have been formulated to further specify in the implementation and achievement of the sustainability goals.

Natural disasters refer to earthquakes, tsunamis and floods as extremely dry periods that are inherent in climate change on planet Earth. 
On the other hand, the Republic of Serbia is committed to increasing the share of renewable energy sources from $21 \%$ to $27 \%$ in gross final consumption by 2020 and $10 \%$ in the transport sector (www.zelenaenergija.pks.rs). Serbia currently uses about $35 \%$ of its total capacity, with particular emphasis on biomass, hydro, geothermal, wind, and solar energy.

In line with the mentioned advantages, the field of alternative energy sources is of immanent importance from the perspective of overall economic growth and development. Namely, renewable resources are considered to have a multiplier effect in the context of increasing the production of equipment for their use, as well as stimulating and diffusing innovation. The growth of innovative potential contributes to a better competitiveness of the economy as measured by GDP levels, as well as to overall trade (import, export) globally. In this regard, greater reliance in production on wind, solar and biomass energy encourages the development of the economy as a whole, as well as of individual segments or industries, e.g. tourism.

\subsection{Sustainable tourism}

Contemporary tendencies and trends have led to the development of a special segment of tourism aimed at improving the quality of life of the local community, preserving the environment, as well as increasing the competitiveness of the tourist offer. It is a question of sustainable tourism, which in addition to the aforementioned advantages, also focuses on the more efficient use of ecological resources, respecting the socio-cultural authenticity of the inhabitants, as well as satisfying the interests of all stakeholders (Janković, 2011).

In this regard, the goals of sustainable tourism are compatible with and are in the process of achieving global long-term sustainability. An important element of sustainable tourism is eco-tourism because of its highest growth potential given the forecasts of the World Tourism Organization.

Accordingly, at European Union level, individual regions develop tourist offerings in accordance with the basic principles of long-term sustainability. At the same time, research on tourism and events is an evolving field and it has moved from a main economic focus to a broader perspective. Given the resonance of wine tourism and the role it has for local and rural development, the interest towards the issue of sustainability in wine is more than warranted. (Montella, M. M, 2017). Otto Savoy in France, Palma de Mallorca in Spain, Strandja in Bulgaria and the city of Bonn in Germany are examples of good eco-tourism practices. Namely, bearing in mind the principles and objectives of sustainable development, these European cities are reaping the benefits of using renewable energy sources, smart modes of transport and green building in order to reduce environmental costs and environmental impact. In addition to the above factors, which greatly contribute to the promotion of eco-tourism offer, a timely response of the state in the form of adequate incentives and subsidies is necessary. Being green or sustainable can became a strategic lever for differentiating their business. Some wineries are born green while other become green for achieving marketing purposes (Santini et al, 2013).

On the other hand, the Republic of Serbia has good predispositions for the development of eco-tourism offer. Good geographical location, climate and natural resources in the form of resources speak in favor of the previous statement. However, Serbia is not using its full potential due to lack of adequate infrastructure, adequate waste management solutions and plans, as well as institutional support. In recent years, there have been some changes and shifts in this context. Namely, the expansion of wine tourism has contributed to the adoption of concrete principles 
of sustainability in the field of tourism. Bearing in mind the advantages of sustainable development, we will look at its importance through the perspective of wine tourism in Serbia, i.e. through improving the competitiveness of the region and the economy in general.

\section{THE NEW RURALITY PARADIGM}

Rural space itself expresses a unique natural, geographical, economic, cultural and social environment. The very definition of rural areas involves different approaches and theoretical views by economists, sociologists, agrarian economists and geographers. This is why there is no one commonly accepted definition of urban and rural space.

It is evident that different criteria exist when setting the boundaries of rural areas, which results in each country defining and classifying settlements according to its specific features. This makes it easier to make meaningful political decisions and development strategies.

Ruralism in itself signifies the peculiarities of behavior, the adoption of a particular lifestyle and the values of the inhabitants of rural areas. By this is generally meant an extensive form of agriculture, small settlements with a pronounced collective consciousness, a marked respect for the environment and life within it. Ruralism is a complex and specific whole of social relations within a rural space. It refers to space, organization, arrangement, relationships in that space, which directly and indirectly shape the rural way of life.

Earlier concepts of rural development (both historically and socially) were based on a top-down approach, i.e. an effort to plan rural development beyond rural space itself. That is why the concept of a new rural paradigm takes into account the interests and needs of the rural population, understanding it as a comprehensive, unique space. It developed in response to the inefficiency of the old development model, where rurality was viewed in the domain of wider social and economic systems and their laws. Recent empirical research is based on a descriptive concept within which new typologies of rural areas are developed, based on functional differences between urban and rural and within rural environments (Bogdanov, 2015, p. 98). The turning point in the new thinking involves the entire rural area, and planning with a new methodology: bottom-up. All of this takes on a global character through Agenda 2000 and Leader programs. These programs followed examples of good practice in the local environment of the most developed countries as well as empirical evidence through a case study. An exogenous agricultural policy model has been replaced by an endogenous one.

New concepts of rural development are expressed through concepts such as:

- „Sustainable livelihood of the rural population” - that integrates theoretical and conceptual viewpoints that the rural population is viewed not only from the field of agricultural activity as a food producer, but also from different perspectives: workforce on the farm, employment, processing on the farm, additional income and the like;

- Social protection - earlier top-down concepts considered the material strength and business cooperation of farms to be prejudiced with the support of external funds. This concept is based not only on the direct disposal of money by those in need in rural areas, but also on public works, employment support measures, facilitated access to land, etc.

New information technologies - in response to the inequalities in the development of certain areas and regions, promotes the availability of information technology for rural population, which should provide easier access to the market. 
A common denominator for recent theoretical concepts and strategies for rural development is the transfer of funds to rural areas, the introduction of new technologies, investment in adequate infrastructure and human capital in rural areas. Such attitudes can contribute to better exploiting the comparative advantages of multifunctional agriculture in the function of rural and sustainable development.

\section{MULTIFUNCTIONAL AGRICULTURE AND RURAL DEVELOPMENT}

One way to promote and develop rural areas is to foster sustainable development and create new employment opportunities, especially for young people and women, as well as implement the latest IT solutions. In this regard, one of the significant goals of agricultural policy is the diversification of farm activities for non-agricultural activities and services and the strengthening of links between agriculture and other sectors of the economy (Jelic et al, 2019).

The Sustainable Development Program has different implementation and different goals in terms of the level of development, i.e. developed and underdeveloped countries. For some, economic growth and development are paramount to the care of environmental problems, while for others this relationship is more or less balanced.

As stated earlier, the concept of sustainable development includes three aspects: environmental, economic and social sustainability. Environmental sustainability concerns the protection of natural resources and the conservation of biodiversity; economic concerns are about higher productivity and growth, and social includes institutional development, participation in decision-making, social cohesion and one's own identity.

For the sake of similarity, just as the focus of sustainable development is on three levels, so is the sustainable development of rural areas focused on three dimensions of development (economic, social and environmental).

The concept of multifunctionality, as well as multifunctionality of agriculture, speaks about the role of agriculture not only in the context of food and raw material production but also agrotechnical measures on improving the quality of the environment, preserving biodiversity, air and water, food safety and quality, animal welfare, etc. Thus, the so-called green corridors and areas of particular importance for the development of rural areas were created, with the idea of productivity and specialization of agricultural production. This implies strict application of ecological standards, development of organic agriculture, gradual reduction of state support to agriculture in rural areas. These measures are delivering results in OECD and European Union countries, which coincides with the significant development of their rural environments, thus confirming the quality of these policies.

The term multifunctionality of agriculture includes the following features and characteristics:

- The contribution of agriculture to the conservation of the environment and biodiversity in rural areas, not only for their users, but also for other and subsequent generations;

- The contribution of agriculture to food security - providing food to everyone at all times;

- Contribution of agriculture to food safety - production of food produced to the highest standards of quality and sanitation; 
- Contribution of agriculture to the development of rural economy - agriculture is seen as a factor of economic growth and development and conservation of rural areas in economic and social sense (Bogdanov, 2015, p. 63).

Multifunctionality of agriculture as a term is differently treated and applied in different countries, especially in EU countries and other countries that have unfavorable conditions for agricultural production.

An inseparable term from the concept of multifunctionality is the concept of sustainable development. Their complementarity is reflected in the modern understanding of the production process and the adequate use of both human and natural resources, all with the aim of strengthening the link between agriculture and other branches of the economy.

One of the goals of the paper is to analyze the multifunctionality of agriculture and to apply the standards of sustainable development from the "perspective of Serbian wine centers".

\section{COMPARATIVE ADVANTAGES OF WINE TOURISM IN VILLAGES OF SERBIA}

Generally speaking, there are about $714 \mathrm{~km}^{2}$ of vineyards in Serbia. Wine production is widespread in Vojvodina (in the north of Bačka, Banat and in the Fruška Gora region), in Šumadija (Oplenac), as well as in the Pčinja region (Aleksandrovac). In this regard, there are several wellknown wineries in Vojvodina, of which we state:

- Winery Zvonko Bogdan, Subotica,

- Winery house Kovačević, Irig (Fruška Gora),

- Winery Swiss Lion, Vršački vinogradi,

- Winery Šapat, Slankamen.

In addition to Vojvodina, wineries are also widely represented in the Šumadija region, due to favorable climatic and location conditions:

- Winery Aleksandrović, Oplenac,

- Pik Oplenac,

- Winery Radovanović.

There are several specifics that characterize and are common to these wineries. Namely, the vineyards are located at a low altitude (about 200-300m), which is characterized by a moderately continental climate. Also, predominantly grown wine varieties are: Merlot, Pinot Grigo, Chardonnay, Cabernet Sauvignon, Muscat Ottonel, etc. Furthermore, besides production potential, wineries can also be considered as carriers of regional and local tourist offer. In other words, in recent years the popularization of the concept of wine culture has contributed to the expansion of wine tourism.

The Zvonko Bogdan winery, located in the immediate vicinity of Subotica, currently produces around 300,000 bottles of wine on an area of $64 \mathrm{ha}, 70 \%$ of which is directed to the domestic market and domestic demand, while $30 \%$ of the total production is exported to regional markets: Montenegro, Bosnia and Herzegovina, and Northern Macedonia. Certainly, one of the goals for the coming period is to export to the European Union market ${ }^{4}$.

\footnotetext{
$4 \quad$ The data presented in the paper was collected during a visit to the winery.
} 
Accordingly, the importance of wine tourism can be analyzed from an economic and social point of view. Economically speaking, the production of wineries not only meets the needs of the market, but also represents a significant item of domestic exports, which ultimately contributes to the growth of gross domestic product-GDP. Increasing production also implies greater employment at the local level, thereby indirectly stimulating rural and regional development. Also, rising tourism revenues are becoming an important component of local budgets. As you know, most wine centers are located in rural areas of Serbia.

On the other hand, the development of wine tourism in Serbia has brought nearer divergent economic and environmental goals, which has made their activity a sustainable component. Namely, in recent years, wine centers have been paying increasing attention to the environmental aspect through investments in the construction of their own wastewater treatment plants and the use of renewable energy sources in the form of solar panels and biomass. More rational use of electricity and heat, recycling of resources and waste, as well as increasing energy efficiency have contributed to lower operating costs, as well as less pollution resulting from wine production. The paradigm shift and the diffusion of innovation on this basis have defined the new comparative advantages of wine centers, which are crucial for better positioning in the European market and increasing regional and overall competitiveness. Also, the positive domino effect encourages greener production through additional infrastructure construction and a greater reliance on alternative energy sources, which ultimately contributes to the development of the industrial and service sectors as drivers of rural tourism. In other words, results at the local level produce broader (global) effects.

In essence, these tendencies indicate positive changes in the business and economic environment, which are reflected in the balanced economic, environmental and social context as a prerequisite for long-term sustainability.

An important aspect when it comes to Serbia's European integrations is respect for the rules of market economy, nurturing corporate culture and brand cult, which should be in line with traditional family values and traditional customs.

Building on this aspect, the imperative is the need for development, tourism among other (including wine), but in a new and more meaningful way. This should be included as part of the overall rural development strategy in the Republic of Serbia.

The goal of improving the quality of life in rural areas through wine tourism is achieving its benefits through the affirmation of a concept that is supposed to revive villages and rural areas while retaining residents, especially young people in them. Especially when we consider the devastating effects of demographic change and rural depopulation.

The activities of the inhabitants of rural areas and rural administration are conditioned by the climatic and terrain characteristics of the area itself. They continue through the organization of numerous cultural events that should contribute to the promotion and development of tourism in these areas, which entails the development of infrastructure (roads, water supply, sewage system...), as well as the employment of local people in non-agricultural activities. It all speeds and contributes to the economic sustainability of the villages and rural areas of Serbia. Designing and organizing life and work in the countryside also includes the opening of numerous workshops (to revive old crafts, folk crafts, art and cultural workshops...), sports games, renovation and opening of cultural and artistic organizations, etc. 
The actuality of best practice models in Europe and Serbia shows that a common feature of all these models, regardless of rural diversity, is their self-sustainability, innovative solutions and adequate strategy.

\section{CONCLUSION}

The analysis of this paper highlighted the importance of adopting sustainable development principles for the functioning of an economy in the long run. With this in mind, the paper has implemented a multidimensional integrative approach with the aim of looking at all the important aspects of long-term sustainability. In this regard, the focus of the work was on the concepts of rural development and multifunctional agriculture, with an emphasis on a particular type of rural tourism - wine tourism in the Republic of Serbia.

Namely, the emergence and development of sustainable tourism, as an essential feature of a multifunctional economy, contributes not only to the development of rural areas, but also to the reduction of devastation of resources and the environment, thus uniting in addition to the economic, ecological and social component. In other words, we can view these concepts as unbreakable links in the process of achieving long-term sustainability.

Particular emphasis in the paper was on the analysis of wine tourism in the Republic of Serbia. As such, it has numerous benefits and positive effects, which further emphasizes the topicality of the topic. First, it contributes to the rural development of the area where the wine centers are located, through employment growth, attracting new investment, and protection of nature and the environment. Second, enhancing the tourist attractiveness of the region through various cultural manifestations further encourages the development of infrastructure as a necessary component of green economies in the context of harnessing the potential of renewable energy and waste management. Last but not least, positive changes in the business and economic environment contribute to increasing the competitiveness of wine production, which ultimately creates a predisposition for export growth to foreign markets.

However, the link between wine tourism and the adoption of sustainability standards is not exclusively one-sided. One of the conclusions of the paper is that the given relation is two-way in character. In other words, the development of wine tourism contributes to a more effective implementation of the principles of sustainability, but on the other hand, sustainable development as a concept and contemporary idea encourages the improvement of winery performance in the context of achieving better economic, environmental and social results. Accordingly, achieving economic sufficiency with minimal environmental impact is an important result of the application of standards and principles of sustainable development. 


\section{REFERENCES}

Bardi, U. (2017). Seneca effect: why growth is slow, but collapse is rapid?. Springer.

Bogdanov, N. (2015). Ruralni razvoj i ruralna politika. Beograd: Poljoprivredni fakultet Univerziteta u Beogradu.

European Environmental Agency (2015). SOER 2015 - The European environment - state and outlook 2015. Synthesis report.

Holmberg, J. (2009). Put ka održivom razvoju. In Održivi razvoj Srbije: naša zajednička budućnost: Nacionalna strategija održivog razvoja (pp. 12-19). Beograd: Ministarstvo za nauku i tehnološki razvoj.

Janković, D. (2011). Održivi turizam. In Putokaz ka obnovljivom razvoju (pp. 366-390). Beograd: Ministarstvo za nauku i tehnološki razvoj.

Jelić, S., \& Jovanović, T. (2018). Selo u vrtlogu promena, Monografija. Beograd: Poljoprivredni fakultet Univerziteta u Beogradu.

Jelić, S., Jovanović, T., \& Gavrić, O. (2019). Households as a main factor of rural and sustainable development in the Republic of Serbia. VIII International symposium on agricultural sciences AgroRes 2019, 16-18 May (pp. 229-240). Trebinje, Bosnia.

Jovanović-Gavrilović, B. (2008). Ciljevi i indikatori održivog razvoja u Evropi. In Nova generacija evropskih dokumenata održivog razvoja i pouke za Srbiju (tematski zbornik) (pp. 31-47). Beograd: Ekonomski fakultet.

Montella, M. M. (2017). Wine tourism and sustainability: A review, Sustainability 9(1):113, Retrieved from: https://www.researchgate.net/publication/312353932_Wine_Tourism_and_ Sustainability_A_Review

Pešić, R. (2012). Ekonomika životne sredine i prirodnih resursa, Beograd: Poljoprivredni fakultet.

Santini, C., Cavicchi, A., \& Casini, L. (2013). Sustainability in the wine industry: Key questions and research trends A. Agric. Food Econ. 1, 1.

Stojadinović, D. (2011). Obnovljivi izvori energije. In Putokaz ka obnovljivom razvoju (pp. 330346). Beograd: Ministarstvo za nauku i tehnološki razvoj.

\section{INTERNET ADDRESSES}

www.zelenaenergija.pks.rs

https://www.rs.undp.org/content/serbia/sr/home/sustainable-development-goals.html 